\title{
O PROCESSO DE CONSOLIDAÇÃO DAS RELAÇÕES DE PRODUÇÃO CAPITALISTAS
}

a gênese das reivindicações dos direitos da mulher na Revolução Francesa

\author{
THE CONSOLIDATION PROCESS OF CAPITALIST RELATIONS OF \\ PRODUCTION
}

the genesis of the vindications of women's rights in the French Revolution

\author{
Pâmella Rafaella Barbosa Vaz ${ }^{1}$ \\ (vazpamella@gmail.com)
}

\section{RESUMO}

Este trabalho tem como objetivo abordar de forma crítica o desenvolvimento das relações de produção capitalistas, bem como a gênese das reivindicações dos direitos da mulher na Revolução Francesa. Desse modo, buscam-se compreender as condições socioeconômicas que propiciaram o surgimento das primeiras reflexões filosóficas e políticas tipicamente modernas acerca da exclusão das mulheres dos direitos políticos e de sua inferiorização na sociedade. Nesse sentido, é possível destacar a obra de Mary Wollstonecraft e Olympe de Gouges, que, ao contestarem as teorias jusnaturalistas, possibilitaram o fomento de um primeiro programa político que atendesse às necessidades das mulheres (camponesas, proletárias e pequeno-burguesas).

Palavras-chave: Relações de Produção Capitalistas. Emancipação Política. Direitos da Mulher.

\begin{abstract}
This paper aims to critically approach the development of capitalist relations of production, as well as the genesis of the vindications of women's rights in the French Revolution. We seek to understand the socioeconomic conditions that made possible the rise of the first typically modern philosophical and political reflections about the exclusion of women from political rights and their inferiorization in society. In this sense, it is possible to emphasize the work of Mary Wollstonecraft and Olympe de Gouges, which, in contesting the theories of natural law, enabled the development of a first political program to attend to the needs of women (peasants, proletarians and petit bourgeois).
\end{abstract}

Keywords: Capitalists Relations of Production. Political Emancipation. Women's Rights.

\section{INTRODUÇÃO}

\footnotetext{
${ }^{1}$ Graduada em Ciências Sociais pela Universidade Estadual Paulista “Júlio de Mesquita Filho" (UNESP). CV Lattes: http://lattes.cnpq.br/1376019725115972. ORCID: https://orcid.org/0000-0002-4735-432X.
} 
O objetivo do presente item é analisar o desenvolvimento do processo socioeconômico e político das revoluções burguesas na segunda metade do século XVIII - a Revolução Industrial (1760) e a Revolução Francesa (1789) - a partir do processo histórico de consolidação do modo de produção capitalista. Com base nesses elementos, buscaremos identificar e esmiuçar o surgimento do que podemos caracterizar modernamente como os direitos civis femininos, isto é, a emancipação política ou civil da mulher - contraditoriamente relacionados à concepção de direito natural que a exclui -, assim como o problema inerente à relação entre capital e trabalho.

Para compreender o processo histórico de como se desenvolveram as transformações econômicas, políticas e sociais ao longo do século XVIII, é preciso retomar um conjunto de ideias e fundamentos que marcaram o início da fase de transição da sociedade feudal para a sociedade capitalista. Segundo Mandel, esse período de transição pode ser caracterizado pela profunda crença na racionalidade e no homem como sujeito de sua própria vida e vontade, capaz de determinar a si próprio e de governar seu destino ao assumir sua liberdade com o uso da razão - em suma, na busca por sua própria emancipação. Portanto, ele não é mais predeterminado e predestinado por leis divinas (MANDEL, 2010, p. 12) como ocorria durante os séculos anteriores - mais particularmente entre o século $\mathrm{V}$ e meados do $\mathrm{XV}$-, resultando, como forma política mais bem acabada na França, no absolutismo monárquico, assim como na produção agrícola e artesanal limitadas à subsistência.

Como aponta Rubin (2014), o processo de implementação de novos setores da indústria francesa às expensas das políticas estatais, por Jean-Baptiste Colbert - ministro de Estado e da economia de Luís XIV - foi submetido ao mais rígido controle estatal devido a seu alto custo. Com a produção voltada principalmente para produtos de luxo e exportação, Colbert instituiu para a manufatura de bens tingidos e tecidos aproximadamente 150 normatizações, com inspetores especiais para controle e cumprimento dessas normas. A política mercantilista defendida por Colbert e seus sucessores foi bem-sucedida em um primeiro momento, mas sua fragilidade ficou evidente em meados do século XVIII, após sua morte. Segundo o autor

A indústria francesa, é verdade, não tinha rivais na produção de produtos de luxo para as necessidades da corte e da aristocracia; [...] no entanto, esses avanços externos apoiavam-se sobre uma base frágil. Num país em que a população era predominantemente formada por camponeses arruinados pelas exações da nobreza e dos oficiais coletores de impostos, a indústria capitalista tinha 
pouco espaço para avançar. [...] Os sonhos da França de ver sua indústria conquistar vastos mercados e colônias estrangeiros não se realizaram. Sua batalha com a Inglaterra pela dominação do mercado mundial, em meados do século XVIII, resultou na vitória da Inglaterra, quando esta tomou o controle das colônias americanas da França e consolidou sua própria posição na Índia. [...] As regulações mesquinhas da indústria, nas quais Colbert havia depositado tantas esperanças de melhoria da qualidade das mercadorias manufaturadas, tornaram-se, na realidade, um obstáculo à introdução de melhorias técnicas, inibindo a diversificação da produção e impedindo que os industriais pudessem se adaptar rapidamente às demandas do mercado. [...] Em meados do século XVIII, não apenas empreendedores, mas também funcionários estatais, passaram a exigir cada vez mais e com maior persistência a abolição da regulação restritiva da indústria que caracterizava a política mercantilista. [...] Tivesse a França uma agricultura desenvolvida, sua indústria poderia ter estabelecido um extenso mercado interno. [...] No entanto, a atrasada e dizimada agricultura da França se mostrou como uma base demasiadamente estreita para o crescimento da indústria capitalista. (RUBIN, 2014, p. 126-128)

Essas mudanças para o pensamento humano, sobretudo com a Revolução Francesa (1789-1799), a partir da qual se intensificaram os processos históricos de formação dos Estados Nacionais modernos, tornam possível analisar como os princípios, direitos políticos e sociais fundamentais são constituídos entre os momentos de rupturas e continuidades. Por conseguinte, pode-se averiguar como atuam as diferentes classes sociais no âmbito das disputas pela hegemonia político-econômica. Não à toa, seria nesse contexto e nesses marcos que se manifestariam as primeiras reivindicações de direitos relativos às particularidades e generalidades das mulheres. Como ressalta D’Atri (2017, p. 47), a “[...] Revolução Francesa, que envolveu todas as classes, todos os setores sociais em sua luta contra o absolutismo, começou com uma revolta dirigida pelas mulheres dos bairros pobres de Paris". Na revolta, nascida contra a escassez e a carestia e caracterizada em muitos momentos como rebeliões e manifestações de massas, as mulheres por vezes utilizavam a violência ou os instrumentos legais e institucionais como meios de luta para dar voz às suas reivindicações e, principalmente, para denunciar suas próprias condições sociais e políticas. Além disso, pretendiam afirmar, pela linguagem filosófica característica do período, que as mulheres não eram indivíduos privados de razão e incapazes de se determinarem plenamente.

\section{O PROCESSO DE TRANSIÇÃO DA SOCIEDADE FEUdAL PARA A SOCIEDADE CAPITALISTA}


Segundo Abrão (1999), o Renascimento, que abrange o período entre meados do século XIV e o fim do século XVI, na Europa Ocidental (Países Baixos, Inglaterra, partes do território da França, Alemanha, Boêmia e Catalunha) e particularmente na Itália - que por causa de sua posição geográfica e do controle do comércio no Mediterrâneo era a região economicamente mais desenvolvida -, constituiu-se como movimento filosófico e cultural essencial para a construção de uma nova concepção de mundo, orientada pela valorização da racionalidade por meio do desenvolvimento da ciência e da técnica.

Influenciado pela revalorização das referências da Antiguidade clássica, o humanismo renascentista propôs uma visão antropocêntrica segundo a qual o homem é o centro do pensamento filosófico, ao contrário do teocentrismo, em que Deus é o centro do pensamento filosófico. Nessa "[...] nova ordem das coisas, o homem de virtú é aquele que tem capacidade individual de saber escolher as ocasiões propícias para, ousadamente, transformar o curso dos acontecimentos" (ABRÃO, 1999, p. 133). Assim, preocupados com a ética, a ciência e a técnica e pautados pela valorização da vontade como arbítrio e da razão individual, tais fundamentos se opuseram à escolástica medieval e contribuíram para o enfraquecimento do dogmatismo religioso e do misticismo.

Essa nova concepção de mundo renascentista, que constitui a origem da cultura moderna, também influenciou o movimento da Reforma Protestante (luteranismo, anglicanismo, calvinismo) no século XVI, ao não reconhecer mais a necessidade de mediações na comunicação com Deus - por meio da Igreja Católica -, o que, por sua vez, contribuiu para o fortalecimento das monarquias nacionais na Inglaterra, na França, em Portugal e na Espanha, com a concentração do poder nas mãos do rei, e não mais na figura do papa. Dessa maneira, com o enfraquecimento da nobreza e da Igreja e o correspondente fortalecimento das monarquias nacionais, também ficou marcada a ascensão de uma nova classe social: a burguesia. Dedicada principalmente às atividades de comércio, finanças e manufatura organizadas em corporações, essa classe passou a financiar os governos monárquicos em troca da proteção estatal aos seus negócios.

Os burgueses, habitantes dos burgos $^{2}$, realizavam suas atividades de comércio e manufatura não apenas para a produção de subsistência, mas também para a produção de mercadorias e a acumulação de meios de produção (capital), o que possibilitou o crescimento

\footnotetext{
2 A palavra burgos tem origem do latim "burgus" e significa "pequena fortaleza" ou "povoado". Os burgos surgiram como habitação dos burgueses durante o período de decadência da sociedade feudal e do crescimento comercial e urbano. Esses burgos formaram também as comunas, um tipo de organização social em que os cidadãos eram considerados livres das imposições do Império Romano, da Igreja ou da nobreza, isto é, podian determinar seu próprio destino (ABRÃO, 1999, p. 131-132).
} 
de seu poder econômico, o desenvolvimento dos burgos em cidades-Estado e a formação de famílias influentes e ricas ${ }^{3}$ - os próprios burgueses. É possível identificar, sobretudo na Itália, o " [...] ambiente propício ao surgimento de uma nova classe, com um novo modo de vida, uma nova mentalidade, uma nova maneira de conceber o mundo e o próprio ser humano" (ABRÃO, 1999, p. 132). Como exemplo, há as inovações e criações técnicas da imprensa, das letras de câmbio e de seguro, dos bancos, fábricas e outros mecanismos relacionados com a economia e a atividade manufatureira.

Foi durante essa fase de transição da sociedade feudal para a sociedade capitalista que predominou a "[...] pequena produção mercantil, dentro da qual os principais produtores - os camponeses e artesãos - são produtores livres e não servos, dispondo de seus próprios meios de produção" (MANDEL, 2001, p. 10). Nessas bases se configuraram a sociedade burguesa e as relações de produção capitalistas ${ }^{4}$, que progressivamente generalizaram a produção de manufaturas e deram origem às fábricas por meio do processo de apropriação privada dos meios de produção e das matérias-primas, de uma nova divisão social do trabalho e da elevação do grau de exploração e opressão, visando a uma crescente expropriação de maisvalor e acumulação de capital.

\section{O DESENVOLVIMENTO DAS RELAÇÕES DE PRODUÇÃO CONSOLIDAÇÃO DO MODO DE PRODUÇÃO CAPITALISTAS}

O processo de desenvolvimento das forças produtivas - correspondentes aos meios de produção (ferramentas, terras, manufaturas e máquinas) e à força de trabalho (o dispêndio de

\footnotetext{
${ }^{3}$ Podemos destacar nas cidades-Estado italianas famílias influentes política e economicamente, como os Médici, da cidade de Florença, os Gonzaga, da cidade de Mantova, e os Sforza, da cidade de Milão, que assim como outros prosperavam economicamente com a decadência da sociedade feudal e também financiavam cientistas, escritores, acadêmicos e artistas.

${ }^{4}$ Como aponta Mandel (2001, p. 10), embora o modo de produção capitalista ainda não seja consolidado e hegemônico entre o século XV e o início do século XVIII, ele "[...] surge inicialmente sob a forma de empreendimento agrícola comercial, indústria domiciliar e manufatura. No primeiro caso, o produtor (camponês) é despojado de suas ferramentas de trabalho (a terra, seus animais e instrumentos) e contratado como operário agrícola ou doméstico na fazenda por um fazendeiro-empresário que produz para o mercado. No segundo caso, o produtor, igualmente despojado, produz para um comanditário capitalista. No terceiro caso, os produtores privados da posse de seus instrumentos já se concentram em grande número sob um mesmo teto. Fazendeiros, comerciantes e empresário, assim como seus assalariados, começam a constituir um mercado interior para as mercadorias (víveres, têxteis, ferramentas, bens de consumo)". Durante esse período, as classes dominantes feudais, a nobreza e o clero, dão início a sua lenta decadência e empobrecimento em relação ao crescimento progressivo do poder econômico da burguesia, embora ainda tenham privilégios conservados. Os trabalhadores assalariados formam uma pequena parcela entre os produtores (camponeses livres e pequenos produtores mercantis) e entre os resquícios de relações servis.
} 
energia física e mental do trabalhador, técnicas etc.) - e das relações de produção do capital, segundo Marx (2013, p. 785), pode ser ilustrado historicamente pelo fenômeno da "assim chamada acumulação primitiva”, que não pode ser entendida como resultado ou consequência do desenvolvimento do modo de produção capitalista (como afirmam Adam Smith e Nassau Senior), senão como seu "ponto de partida", ou seja, a acumulação capitalista prévia que criou as condições concretas e necessárias para sua consolidação.

As relações de produção, segundo Mandel, são uma atividade social que pode assumir diferentes formas, pois depende dos modos de organização social e das correspondentes técnicas de produção de uma sociedade e de como são desenvolvidas as relações de trabalho, produção e reprodução da vida social, caracterizadas por relações de produção específicas, que "determinam o conjunto das "relações econômicas"” (MANDEL, 2001, p. 32). Cada modo de produção particular possui formas características de propriedade; a propriedade privada moderna, entendida como uma apropriação privada e uma necessidade do modo de produção capitalista, transforma os meios de produção e subsistência em capital a partir de especificidades do capitalismo, como a apropriação do excedente criado pelos trabalhadores por meio da venda de sua força de trabalho, transformada em mercadoria no capitalismo. Seu consumo ou uso cria novo valor, substituindo não apenas seu valor original, mas gerando mais-valia.

A propriedade privada dos meios de produção, entendida como mecanismo de monopolização dos meios de produção utilizado pela burguesia, é uma forma de expropriação do excedente econômico ou do trabalho não pago produzido pelos trabalhadores, em que o trabalho humano e as condições para a realização do trabalho social independem da força de trabalho, alienando o trabalhador dos meios e de seu próprio produto. A força de trabalho (capacidade de produção) é transformada em mercadoria na sociedade burguesa e vendida pelos trabalhadores na forma de salários, sendo esse o único meio de produção da atividade de trabalho que os trabalhadores detêm, pois faltam-lhes os meios e as condições necessárias para a produção. A burguesia necessita da força de trabalho para transformar dinheiro em capital: na forma do salário, que é pago pelo custo da reprodução da força de trabalho, e na forma do "valor adicional" que ultrapassa o valor dos salários ao produzir e acrescentar valor, chamada por Marx de mais-valia. Esse conceito consiste na "diferença entre o valor produzido pelo trabalhador ou trabalhadora e os custos de reprodução da força de trabalho" (MANDEL, 2001, p. 41). Desse modo, as relações sociais de produção no capitalismo dependem da forma privada dos meios de produção e da 
mercantilização e objetificação da força de trabalho, pois há uma relação intrínseca entre eles a qual configura a singularidade do modo de produção capitalista.

As relações de produção capitalistas aparecem, portanto, de forma esporádica em algumas cidades da Europa Ocidental, entre os séculos XIV e XV, e nas cidades do Mediterrâneo, a partir do século XVI, impulsionadas principalmente pelas economias mercantis e o movimento de expansão das rotas marítimas e comerciais - como a pilhagem do continente africano a partir do comércio, tráfico e utilização da força de trabalho escravo de negros africanos, e o "descobrimento" do continente americano ${ }^{5}$ - enquanto as mais notáveis fontes de acumulação de capital.

Acerca das origens históricas do capital e das relações capitalistas, podemos explicálas a partir do processo de "separação entre o trabalhador e a propriedade das condições de realização de seu trabalho", o que só pode ser realizado na medida em que "duas espécies bem diferentes de possuidores de mercadorias se defrontem e estabeleçam contato" (MARX, 2013, p. 786). Assim, são criadas duas classes distintas: uma de trabalhadores assalariados, sem propriedades e obrigados a vender sua própria força de trabalho; outra, uma rica burguesia (possuidora de grandes quantidades de dinheiro e instrumentos de trabalho; proprietária de terras, manufaturas e posteriormente fábricas etc.), que compra a força de trabalho de outros com o intuito de valorizar seu próprio montante de valor, como aponta Hunt (1981, p. 239). Nesse sentido, esse processo de acumulação primitiva

[...] desempenha na economia política aproximadamente o mesmo papel do pecado original na teologia. Adão mordeu a maçã, e com isso o pecado se abateu sobre o gênero humano. Sua origem nos é explicada com uma anedota do passado. Numa época muito remota, havia, por um lado, uma elite laboriosa, inteligente e sobretudo parcimoniosa, e, por outro, uma súcia de vadios a dissipar tudo o que tinham e ainda mais. [...] Deu-se, assim, que os primeiros acumularam riquezas e os últimos acabaram sem ter nada para vender, a não ser sua própria pele. E desse pecado original datam a pobreza da grande massa, que ainda hoje, apesar de todo o seu trabalho, continua a não possuir nada para vender a não ser a si mesma, e a riqueza dos poucos, que cresce continuamente, embora há muito tenham deixado de trabalhar. [...] Mas tão logo entra em jogo a questão da propriedade, torna-se dever sagrado sustentar o ponto de vista da cartilha infantil como o único válido para todas as faixas etárias e graus de desenvolvimento. Na história real, como se sabe, o papel principal é desempenhado pela conquista, a

\footnotetext{
${ }^{5}$ Ao tratar da gênese do capitalismo industrial e da transição da sociedade feudal para a sociedade capitalista, Marx comenta: "A descoberta das terras auríferas e argentíferas na América, o extermínio, a escravização e o soterramento da população nativa nas minas, o começo da conquista e saqueio das Índias Orientais, a transformação da África numa reserva para a caça comercial de peles-negras caracterizam a aurora da era da produção capitalista. Esses processos idílicos constituem momentos fundamentais da acumulação primitiva' (MARX, 2013, p. 821).
} 
subjugação, o assassínio para roubar, em suma, a violência. [...] Já na economia política, tão branda, imperou sempre o idílio. Direito e "trabalho" foram, desde tempos imemoriais, os únicos meios de enriquecimento, [...] na realidade, os métodos da acumulação primitiva podem ser qualquer coisa, menos idílicos. (MARX, 2013, p. 785-786)

O fenômeno da acumulação primitiva constitui, então, o violento processo histórico de separação entre produtor e meio de produção; em outras palavras, representa a destruição dos tradicionais vínculos sociais, ou seja, a transformação das "relações de propriedade feudal" em "relações de propriedade privada moderna" (HUNT, 1981, p. 240). Em um primeiro momento, esse processo "transforma em capital os meios de subsistência e de produção" e, em um segundo, "converte os produtores diretos em trabalhadores assalariados" (MARX, 2013, p. 786).

Esse processo de transição propicia o desenvolvimento das forças produtivas e das relações de produção capitalistas, que ocorre a partir da formação violenta do proletariado moderno, por meio do processo de espoliação das propriedades fundiárias camponesas e dos instrumentos de trabalho dos artesãos, transformando-se o produtor direto - o trabalhador em vendedor de sua própria força de trabalho como forma de subsistência. O capitalista, por sua vez, tem como fonte de lucro parte do excedente produzido pela atividade de trabalho do conjunto de trabalhadores que lhe vendem sua força de trabalho. Sobre o processo histórico de espoliação, Marx escreve

$\mathrm{Na}$ história da acumulação primitiva, o que faz época são todos os revolucionamentos que servem de alavanca à burguesia em formação, mas, acima de tudo, os momentos em que grandes massas humanas são despojadas súbita e violentamente de seus meios de subsistência e lançadas no mercado de trabalho como proletários absolutamente livres. A expropriação da terra que antes pertencia ao produtor rural, ao camponês, constitui a base de todo o processo. Sua história assume tonalidades distintas nos diversos países e percorre várias fases em sucessão diversa e em diferentes épocas históricas. (MARX, 2013, p. 789)

Ainda assim, Marx observa que a formação dessa nova classe de trabalhadores livres das relações sociais de servidão baseia-se em uma legislação empregada pelo Estado através de decretos que "cercam" as terras comunais e expulsam os camponeses por meio da expropriação e espoliação de suas terras, para que, com isso, eles passem a servir como força de trabalho nas cidades. Mesmo com a formação violenta e a imposição do assalariamento, não é possível absorver completamente aquela massa de proletários - gerando-se um grande contingente de desempregados -, pois, além do 
processo de proletarização, ocorre a pauperização da população expropriada, transformando-a em mendigos, ladrões e indivíduos marginalizados socialmente. Dessa forma, cria-se uma necessidade de disciplinar a nova força de trabalho manufatureira (e posteriormente industrial), por meio de uma rígida adaptação ao trabalho assalariado, com punições severas (torturas e chicotadas) para controlar os desempregados "indisciplinados" e as guerras camponesas. Ao analisar particularmente a Inglaterra, tendo em vista a "forma clássica" de expropriação e o local onde a maquinaria ganhou maior eficiência e destaque com a Revolução Industrial, o autor ressalta

O roubo dos bens da Igreja, a alienação fraudulenta dos domínios estatais, o furto da propriedade comunal, a transformação usurpatória, realizada com inescrupuloso terrorismo, da propriedade feudal e clânica em propriedade privada moderna, foram outros tantos métodos idílicos da acumulação primitiva. Tais métodos conquistaram o campo para a agricultura capitalista, incorporaram o solo ao capital e criaram para a indústria urbana a oferta necessária de um proletariado inteiramente livre. (MARX, 2013, p. 804)

\title{
E continua
}

\begin{abstract}
Os diferentes momentos da acumulação primitiva repartem-se, agora, numa sequência mais ou menos cronológica, principalmente entre Espanha, Portugal, Holanda, França e Inglaterra. Na Inglaterra, no fim do século XVII, esses momentos foram combinados de modo sistêmico, dando origem ao sistema colonial, ao sistema de dívida pública, ao moderno sistema tributário e ao sistema protecionista. Tais métodos, como por exemplo o sistema colonial, baseiam-se, em parte, na violência mais brutal. Todos eles, porém, lançaram mão do poder do Estado, da violência concentrada e organizada da sociedade, para impulsionar artificialmente o processo de transformação do modo de produção feudal em capitalista e abreviar a transição de um para o outro. A violência é a parteira de toda sociedade velha que está prenhe de uma sociedade nova. (MARX, 2013, p. 821)
\end{abstract}

A consolidação do modo de produção capitalista ocorre por meio da privatização e concentração dos meios de produção, de uma nova divisão social do trabalho, da elevação do grau de exploração e opressão da atividade laboral, além de uma maior expropriação de maisvalor e acumulação de capital. Concomitantemente, a ascensão política da burguesia como classe social é um dos fatores responsáveis por superar as antigas relações sociais e limites que impediam o desenvolvimento da produção econômica e de novas formas de exploração do homem pelo homem.

Desse modo, a emancipação que as revoluções liberais burguesas posteriores a essa consolidação econômica promovem diz respeito somente às 
relações sociais de servidão e escravidão. $\mathrm{Na}$ medida em que os trabalhadores se tornam proprietários de sua força de trabalho e cidadãos - passando as relações de trabalho a se organizarem em termos contratualistas, buscando transformar a exploração feudal em exploração capitalista -, o avanço da sociedade burguesa amplia seu aspecto contraditório, conforme o antagonismo e os conflitos entre ricos e pobres crescem na sociedade. Ou seja, não há apenas um progresso político-econômico com o avanço do conhecimento, da técnica e da acumulação de riquezas, mas também um acúmulo de explorações, opressões, injustiças e de negação dos direitos fundamentais da humanidade. É a partir dessa tomada de consciência que emergem novas manifestações da luta de classes, uma nova prática social completamente atrelada às contradições resultantes dos interesses do capitalismo, isto é, entre as novas classes sociais e suas tendências.

Segundo Hobsbawm, mediante o surgimento da Revolução Industrial, “[...] pela primeira vez na história da humanidade, foram retirados os grilhões do poder produtivo das sociedades humanas, que daí em diante se tornaram capazes da multiplicação rápida, constante, e até o presente ilimitada, de homens, mercadorias e serviços" (HOBSBAWM, 2016, p. 59). Os servos, camponeses e artesãos se tornam completamente livres das determinações de seus senhores, monarcas e chefes de corporações de ofício; mas, ao mesmo tempo, isso significa que em nenhuma outra sociedade ou período histórico até ali havia se aberto a possibilidade de realização de um processo de acumulação na mesma intensidade.

\section{AS REVOLUÇÕES BURGUESAS}

As revoluções burguesas se deram no século XVIII - conhecido como o "Século das Luzes", Iluminismo ou também Esclarecimento [Aufklärung $]^{6}$, no sentido de iluminar, ilustrar, ou fornecer as luzes. Esse foi um movimento filosófico-político e cultural que sintetizou as bases ideológicas para a ruptura com a estrutura e concepção de mundo feudal e

\footnotetext{
${ }^{6}$ O filósofo alemão Immanuel Kant (2013, p. 63-64), em resposta à pergunta "que é Esclarecimento [Aufklärung]?", diz: o "Esclarecimento [Aufklärung] é a saída do homem de sua menoridade, da qual ele próprio é culpado. A menoridade é a incapacidade de fazer uso de seu entendimento sem a direção de outro indivíduo. $\mathrm{O}$ homem é o próprio culpado dessa menoridade se a causa dela não se encontra na falta de entendimento, mas na falta de decisão e coragem de servir-se de si mesmo sem direção de outrem. Sapere aude! Tem coragem de fazer uso de teu próprio entendimento, tal é o lema do esclarecimento [Aufklärung]". Kant, que estava ligado aos ideais da revolução burguesa alemã, buscava compreender o papel da ruptura das tradições da idade das trevas em oposição ao Iluminismo, isto é, se o homem era capaz de agir como sujeito, de governar e dirigir a própria vida agindo conforme a razão e sair desse "estado de menoridade", de tutela, que o impedia de se emancipar.
} 
a consolidação da burguesia como classe dirigente e dominante, a partir da compreensão filosófica

[...] [Jusnaturalista], que consiste em atribuir ao indivíduo direitos originários e inalienáveis; [contratualista], que consiste em considerar a sociedade humana e o Estado como fruto da convenção entre indivíduos; [liberal econômica], própria da escola fisiocrática, que combate a intervenção do Estado nos assuntos econômicos e quer que estes sigam exclusivamente seu curso natural, [e como] consequência global das doutrinas precedentes, negação do absolutismo estatal e redução da ação do Estado a limites definidos, mediante a divisão dos poderes. O postulado fundamental dessa fase do liberalismo é a coincidência entre interesse público e privado. (ABBAGNANO, 2007, p. 696)

É fundamental ressaltar a necessidade política em que se forjou a burguesia. Essa classe precisou, à medida que se tornava uma classe social hegemônica, apresentar suas necessidades sociais e econômicas como universais, a fim de que fossem tomadas como o único caminho capaz de superar os problemas que a totalidade da sociedade (as demais classes e grupos sociais) enfrentavam. Em outras palavras, a propagação dos princípios e ideais burgueses como universais e necessários foi fundamental para a consolidação das relações e do modo de produção capitalistas, uma vez que serviu como ponto de convergência e propulsor do programa político e revolucionário burguês. O próprio Marx, em sua juventude - e em debate com o movimento dos jovens hegelianos -, lidou com essa questão ligada aos conceitos de emancipação política e humana. Segundo a interpretação de Trotsky acerca da Revolução Francesa

Comparadas com a grande revolução, a prussiana ou a austríaca surpreenderam por sua falta de brilho. Por um lado, chegaram demasiado cedo. Por outro, demasiado tarde. O gigantesco esforço que a sociedade burguesa precisa para acertar contas radicalmente com os senhores do passado só pode ser conseguido ou mediante a poderosa unidade da nação inteira, que se levanta contra o despotismo feudal, ou mediante uma evolução acelerada da luta de classes dentro dessa nação em vias de emancipação. O primeiro caso se deu entre 1789 e 1793. Toda a energia nacional que se havia acumulado na tremenda resistência contra a velha ordem foi totalmente gasta na luta contra a reação. No segundo caso, que até agora não se deu na história e que consideramos apenas como uma possibilidade, se produz, dentro da nação burguesa, o grau de energia necessário para conseguir a vitória sobre as forças obscuras do passado, mediante uma luta de classes "interna". Os ásperos conflitos internos que consomem grande parte de suas energias e privam a burguesia da possibilidade de desempenhar o papel principal levam seu antagonista, o proletariado, adiante, lhe dão em um mês a experiência de décadas, o colocam na frente mais avançada e lhe 
entregam as rédeas do poder, ocasião que aproveita para, decididamente e sem vacilações, dar aos acontecimentos um poderoso ímpeto. (TROTSKY, 2010, p. 59-60)

Em relação à repercussão desse período de radicalização na ilha de São Domingos, em 1789 - a partir da convocação dos Estados Gerais; da proclamação do Terceiro Estado como Assembleia Nacional, e posteriormente, Constituinte; da queda da Bastilha; da elaboração da Declaração de Direitos do Homem e do Cidadão; e do "período do terror" -, houve um impacto profundo, chegando a intensificar-se a chama que deu início à Revolução Haitiana ${ }^{7}$, em 1791. Iniciou-se, assim, a libertação da ilha da dominação francesa, sendo essa a primeira colônia a acabar com as relações escravistas, fundando-se a primeira república negra moderna. No mesmo ano, a Assembleia Constituinte estabeleceu a igualdade de direitos em São Domingos, provocando revoltas e rebeliões de escravos. Ainda segundo Trotsky

No período heroico da história francesa, vemos diante de nós uma burguesia ilustrada e ativa que ainda não havia descoberto suas próprias contradições. A história lhe havia confiado a tarefa de direção na luta pela nova ordem, não apenas contra as instituições antiquadas da França, mas também contra as forças reacionárias de toda a Europa. Consequentemente, em todas as suas diversas frações, a burguesia se sente a líder da nação, reúne as massas para o combate, lhes transmite as palavras de ordem e lhes mostra a tática da luta. A democracia unificou a nação sob uma ideologia política. O povo pequenos burgueses, camponeses e operários - elegia burgueses como deputados e as tarefas confiadas a eles por seus eleitores eram inscritas na linguagem de uma burguesia consciente do seu papel messiânico. Embora durante a revolução também apareçam claramente antagonismos de classe, a inércia da luta revolucionária afastava continuamente do caminho os elementos mais conservadores da burguesia. Nenhuma camada social é descartada antes de ter transmitido sua energia às que a sucedem. Assim, a nação como um todo continua a luta por seus objetivos com meios cada vez mais poderosos e decididos. Quando as camadas superiores da burguesia rica se separam do núcleo do movimento nacional posto em marcha e se aliam com Luís XVI, as demandas democráticas da nação são dirigidas contra tal burguesia, e isso leva ao sufrágio universal e à república como formas lógicas e inevitáveis da democracia. (TROTSKY, 2010, p. 60-61)

Dessa maneira, o período de crise e carestia no governo de Luís XVI, que gerou as condições para o início do processo revolucionário francês, estabeleceu-se sobre a frágil base do desenvolvimento agrícola atrasado (sob as regulações restritivas da indústria, típicas do mercantilismo) e da predominância da população camponesa miserável e exaurida pelos altos impostos e obrigações feudais. Esses eram os principais motivos que impediam a

\footnotetext{
${ }^{7}$ JAMES, Cyril Lionel Robert. Os jacobinos negros: Toussaint L'Ouverture e a revolução de São Domingos. São Paulo: Boitempo, 2010.
} 
expansão e a consolidação da indústria capitalista francesa no século XVIII, bem como o desenvolvimento de novas técnicas de produção e formas de propriedade e relações de produção (RUBIN, 2014, p. 127-129). Isso se deu diferentemente da Inglaterra, que havia passado por uma transformação sociopolítica com a Revolução Gloriosa entre 1688 e 1689, responsável por romper com o absolutismo e instaurar uma Monarquia Constitucional, na qual antigos direitos feudais foram abolidos com a reconfiguração da monarquia inglesa submetida ao parlamento.

Por conseguinte, o liberalismo - que aflorou durante o Iluminismo como uma doutrina filosófico-política, tendo como seus principais expoentes Voltaire, Diderot, Montesquieu, Rousseau - tinha como objetivo a liberdade no campo político e econômico, visto que foi capaz de sintetizar para o pensamento liberal e burguês a necessidade de romper com o absolutismo teológico e a estrutura feudal.

\section{A REVOLUÇÃO FRANCESA E A IDENTIFICAÇÃO DA MULHER COMO SUJEITO}

A França, que era conhecida como "República das Letras" pelos cidadãos livres e iguais, autodenominados "les philosophes", era uma sociedade monárquica dividida em estados rigorosamente fechados ${ }^{9}$, com uma base produtiva frágil e atrasada, além de uma produção que impedia o desenvolvimento da indústria capitalista. Apesar da predominância

\footnotetext{
${ }^{8}$ Os filósofos ("les philosophes") eram escritores que buscavam adentrar o círculo sociocultural e político francês em busca de reconhecimento e remuneração, pois, com recursos escassos, não tinham outro ofício se não o de escritores. Com origens diversas, desde a burguesa, nobre, religiosa, ou sem condição social definida, esses filósofos tiveram um enorme alcance no que diz respeito à livre circulação de ideias e pensamento, o que resultou em perseguições, prisões e exílios, resultados da defesa e da prática da liberdade. Esses escritores ficaram conhecidos como "enciclopedistas" por escreverem sobre assuntos diversos e por a Enciclopédia ser de fato a grande obra de todos eles. Tal grupo não destinava seus escritos apenas para o público especialista ou pertencente às classes dominantes, nobres e clericais, mas sim para o público não especialista, sobre o qual pretendia "lançar as luzes", o que significa um rompimento com os valores estabelecidos, sejam eles morais, religiosos ou sobretudo filosóficos e políticos (ABRÃO, 2007, p. 267-271).

${ }^{9}$ A sociedade francesa era dividida juridicamente em: Primeiro Estado, constituído pelo alto clero e o baixo clero, sendo que o primeiro se identificava com a nobreza e o segundo, com o povo; Segundo Estado, constituído pela nobreza - a corte, a nobreza provincial e a nobreza de toga (juízes e altos funcionários), que, embora não fosse nobre de nascimento, comprava títulos de nobreza e o transmitia de forma hereditária; o Terceiro Estado, constituído pelos burgueses, os camponeses sem terra e os "sans-culottes" - chamados assim por causa das calças simples que usavam, diferente do vestuário luxuoso dos nobres -, uma camada heterogênea composta por artesãos, aprendizes, proletários e pequenos proprietários. O Primeiro e o Segundo Estados também formavam a aristocracia, um grupo que explorava e oprimia o Terceiro Estado através da cobrança de impostos contribuições, pois, além de usufruírem da isenção tributária, usufruíam do tesouro real com pensões e cargo públicos e clericais (MORIN, 2013, p. 75).
} 
agrícola, existia a base da indústria de artigos de luxo destinada à corte, à aristocracia e à exportação (RUBIN, 2014, p. 127).

A contribuição da gama de pensadores iluministas foi fundamental para a construção de uma nova interpretação e redefinição do homem, orientada pela razão e pela capacidade de se determinar. Como resultado das relações e experiências condicionadas pelo meio social, o ser humano pôde ser educado a deixar de viver sob o véu da arbitrariedade e transformar a si mesmo - como é o caso particular das mulheres que passam a se reivindicar como sujeitas, o que, segundo Morin (2013, p. 95), significa uma forma de "consciência das [necessidades de] mudanças radicais na organização política, social e econômica do país, as quais necessariamente afetariam seu círculo familiar e camada social”. Imersa nesse contexto de ideias políticas e discussões filosóficas, a Revolução Francesa possibilitou o rompimento com o Antigo Regime após uma profunda crise econômica do governo de Luís XVI.

A Revolução Francesa foi um processo revolucionário político-econômico realizado por meio da articulação e mobilização das forças sociais para a derrubada do absolutismo monárquico. Após a consolidação do poder econômico da burguesia com a Revolução Industrial na Inglaterra, e devido às relações de apoio mútuo com os governos monárquicos, a burguesia se via impedida de se desenvolver livremente pelas instituições semifeudais, que passaram a ser obstáculos para a consolidação de seu poder político. Desse modo, a burguesia buscou por apoio no Terceiro Estado, articulando e agitando seu programa econômico e político para as massas em busca de uma unidade da nação contra as forças do Antigo Regime. Embora essa relação de aliança da burguesia com o Terceiro Estado tenha se estabelecido num primeiro momento, ainda existiam disputas internas pela direção política e econômica desse processo, gerando divergências de interesses entre as classes sociais. A partir desses elementos gerais, é possível compreender como foram desenvolvidos os respectivos conflitos sociopolíticos e econômicos entre os anos de 1789 e 1799 .

A convocação dos Estados Gerais ${ }^{10}$ por Luís XVI para maio de 1789 marca o início do período de efervescência política na França. Esse mecanismo utilizado pelo rei como uma forma de consulta aos súditos nada mais era do que uma maneira de obter consenso para votar subsídios fiscais, uma vez que o tesouro nacional estava quase em falência. Com o crescimento da insatisfação das diversas camadas sociais e das exigências de reformas políticas e sociais (inspiradas pelo espírito iluminista), cartas, petições e manifestações foram

${ }^{10}$ Os Estados Gerais eram uma assembleia formada por representantes eleitos do clero, da nobreza e do Terceiro Estado com o objetivo de votar medidas tributárias para resguardar o tesouro público francês. Os representantes dos Estados Gerais não tinham autoridade para governar e nem para legislar; além disso, eles não se reunian desde 1614 (MORIN, 2013, p. 35). 
produzidas, inclusive por mulheres - apesar de ainda serem minoritárias, já que "consideravase que elas estavam naturalmente representadas pelos homens da família" (MORIN, 2013, p. $35)$.

Essa perspectiva, fundamentada principalmente em princípios teológico-naturalistas, limitava e manifestava a incapacidade de compreender a totalidade da realidade social e política dos setores aristocráticos e institucionais, formados majoritariamente por homens. Destaca-se o fato de que as mulheres já se encontravam incorporadas como força de trabalho em diversas áreas no mesmo século - como a prataria, a encadernação, a papelaria, o comércio de alimentos, a costura e pequenas atividades de rua; havia até mesmo corporações de ofício exclusivamente femininas, como as das floristas e das vendedoras de peixe (MORIN, 2013, p. 38-39).

Nos citados documentos elas pediam "mais esclarecimento, mais educação e igualdade perante a lei para os dois sexos, [...] a lei do divórcio e treinamento profissional para conquistar a independência financeira, [...] necessidade de moral e bons costumes (moeurs) para reformar a sociedade" (MORIN, 2013, p. 36). Além disso, era materialmente contrastante a inferioridade dos salários pagos às mulheres frente aos pagos aos homens ao exercerem uma mesma atividade. Ainda vale ressaltar a existência de grupos de mulheres, como as comerciantes de mercado, que tinham ligações diretas com o rei devido à sua importância para as relações de comércio da comunidade e manutenção da família, destacando-se o papel estabelecido por elas na sociedade, na qual eram "responsáveis pelo orçamento doméstico e pela alimentação da família" (MORIN, 2013, p. 74). Em períodos de escassez, carestia e crise, as mulheres já eram as que mais sofriam, pois eram diretamente responsáveis pelo cuidado e manutenção da vida doméstica, o que, por sua vez, motivava-as a participar da vida pública e política, servindo por vezes como "termômetro das massas", dada sua posição social estratégica.

Em junho de 1789, a Assembleia Nacional substituiu os Estados Gerais, devido às tentativas do rei de conter as reformas impulsionadas pelo povo. Com isso, a população parisiense formou milícias (organizações militares populares) e se direcionou para a tomada da Bastilha" ${ }^{11}$ em julho de 1789. Apesar do "estabelecimento do caráter masculino do embate revolucionário", fica evidente que "as mulheres do povo estavam presentes desde os primeiros momentos da Revolução" (MORIN, 2013, p. 70). Desde a convocação dos Estados Gerais, a

\footnotetext{
${ }^{11}$ A Bastilha era uma fortaleza que havia sido transformada em prisão, um símbolo do absolutismo. A tomada d Bastilha marca o início do processo revolucionário (MORIN, 2013, p. 69-70).
} 
presença feminina foi se tornando mais ativa e incidente - especialmente na vida pública -, chegando-se ao ponto, inclusive, de as mulheres participarem dos levantes e das frentes de avanço do processo revolucionário.

Com o início da Assembleia Nacional Constituinte (junho de 1789 a setembro de 1791), a burguesia organizou a Guarda Nacional e estabeleceu a Comuna, uma forma de governo provisória para controlar os ânimos das massas, pois se temia uma radicalização. Em agosto de 1789, foi aprovada a Declaração dos Direitos do Homem e do Cidadão e, em setembro de 1791, sancionou-se a Constituição francesa. Na Constituição, foi dissolvida a monarquia da Assembleia Nacional e instituída uma Monarquia Constitucional, com a separação dos três poderes (Legislativo, Judiciário e Executivo, embora o rei ainda pudesse designar seus ministros). Foram abolidas

[...] instituições que feriam a liberdade e a igualdade e os títulos de nobreza, as distinções hereditárias, as distinções das ordens feudais, a herança de juízes e quaisquer títulos, denominações e prerrogativas derivadas ou de qualquer ordem de cavalaria e quaisquer condecorações. [Aboliram-se], também, as distinções envolvidas de nascimento ou de qualquer outra superioridade de funcionários públicos no exercício de suas funções. (PEIXINHO, 2012, p. 4)

Contudo, a definição de direitos dos cidadãos se limitava à distinção entre ativos e passivos - os ativos eram os que pagavam impostos, podiam servir à Guarda Nacional e participar das eleições; os passivos eram os que não conseguiam pagar a alta taxa de impostos requerida, não podiam votar e nem portar armas -, o que restringiu a participação política das mulheres pelo voto censitário, especialmente as proletárias e pobres, evidenciando-se seu não reconhecimento como cidadãs. Sobretudo, o período entre 1789 e 1791 marca o surgimento, em Paris e nas províncias, de "associações mistas e femininas [...] que aos poucos se transformaram em clubes políticos" (MORIN, 2013, p. 24) - como o caso da Sociedade das Cidadãs Republicanas Revolucionárias ${ }^{12}$, fundado por Claire Lacombe ${ }^{13}$ e Pauline León ${ }^{14}$.

\footnotetext{
${ }^{12}$ A Sociedade das Cidadãs Republicanas Revolucionárias, fundada em maio de 1793, durante o auge da radicalidade do processo revolucionário, era formada por mulheres sans-culottes, comerciantes de rua, artesãs e assalariadas (proletárias, camponesas e pequeno-burguesas). Embora não fosse um clube político propriamente "feminista", pois esse termo ainda não existia no século XVIII, ele possibilitou a articulação e radicalização das mulheres ativistas, militantes e das atividades durante a Revolução, como a exigência da não taxação dos gêneros de primeira necessidade e a vigilância e perseguição aos contrarrevolucionários, como os girondinos e aristocratas (MORIN, 2013, p. 163).

${ }^{13}$ Claire Lacombe (1765-1809?) foi uma jovem atriz e uma das fundadoras da Sociedade das Republicanas Revolucionárias durante a Revolução Francesa. Claire participou do combate violento e da tomada do Palácio das Tulherias - onde residia a família real - em agosto de 1792, que marcou a vitória dos revolucionários e o fin da monarquia e da distinção entre cidadãos ativos e passivos (MORIN, 2013, p. 164).
} 
Esses clubes políticos possuíam um caráter particularmente entrelaçado ao período, com a defesa dos princípios republicanos e de uma visão de mundo antidogmática. Embora existissem diferentes tendências nas mulheres, mais radicais ou mais moderadas, era notável a dificuldade de centralização e unidade.

A partir desse contexto, é possível destacar duas questões que marcam os primeiros apontamentos de insuficiência desse programa revolucionário burguês em efetivar os direitos que haviam assumido como universais. Com os dois primeiros escritos, marca-se na história moderna o início das reivindicações das mulheres como "parte do povo soberano, e [que por isso] passaram a se intitular cidadãs (citoyennes) ${ }^{15}$, usando a palavra não mais como esposas e filhas de cidadãos, mas em sua acepção política, de pertencimento à cidade e ao conjunto da nação" (MORIN, 2013, p. 122).

Em resposta à Declaração dos Direitos do Homem e do Cidadão (1789), Olympe de Gouges escreveu a Declaração dos Direitos da Mulher e da Cidadã em $1791^{16}$ : um manifesto político redigido para aprovação na Assembleia Nacional. Com o mesmo sentido contestatório, e em resposta à recém-promulgada Constituição de 1791, Mary Wollstonecraft escreveu a Reivindicação dos Direitos da Mulher, em $1792^{17}$ - a primeira reflexão filosófica acerca da igualdade de gêneros. Nela, procurou debater com os principais pensadores e teóricos do período iluminista francês, como Jean-Jacques Rousseau e Alexander Pope, que se utilizaram de uma argumentação baseada na razão para inferiorizar a mulher. Segundo Morin

Muitos homens [...] eram reticentes ou hostis à atuação das associações femininas quando suas atividades ultrapassavam a filantropia para entrar no terreno político - e masculino [...]. Ironicamente, todos se justificavam com os argumentos de Rousseau, fazendo leituras diferentes de seus escritos: as mulheres enxergavam a exaltação das mães e a responsabilidade pela formação dos bons costumes; os homens notavam a demarcação sexual dos papéis e a domesticidade feminina. (MORIN, 2013, p. 130)

\footnotetext{
14 Pauline León (1768-1838), que ao lado de Claire Lacombe fundou a Sociedade das Republicanas Revolucionárias e participou da tomada do Palácio das Tulherias, defendia o direito de as mulheres se armarem para defender a nação, assim como seus direitos políticos de cidadania. Para ela, era necessária a criação de uma Guarda Nacional feminina, pois, se as mulheres haviam lutado como cidadãs, também precisavam de armas como cidadãs para defender a si mesmas e à pátria (MORIN, 2013, p. 164).

${ }^{15}$ Acerca da discussão acerca do significado do que é ser cidadão na França no fim do século XVIII: “[...] o governo jacobino interpretou o significado de homem segundo suas conveniências: quando se tratava de impostos e leis penais, a categoria homem incluía as mulheres (sentido homo, todos), porém, se a questão fossem os direitos políticos, educacionais e sociais, homem adquiria o sentido mais restrito de masculino (sentido vir, só o sexo masculino)" (MORIN, 2013, p. 122).

${ }^{16}$ ASSMANN, Selvino José. Declaração dos Direitos da Mulher e da Cidadã - por Marie Gouze, "Olympe de Gouges" (1791). In: Revista Internacional Interdisciplinar INTERthesis, Florianópolis, v. 15, n. 1, fev. 2018.

${ }^{17}$ WOLLSTONECRAFT, Mary. Reivindicação dos direitos da mulher. São Paulo: Boitempo, 2016.
} 
Olympe de Gouges, pseudônimo de Marie Gouze (1748-1793), foi uma dramaturga e abolicionista que criticou de forma radical a sociedade francesa, que negava às mulheres direitos políticos e sociais. Guilhotinada em 1793, durante o Período do Terror - em razão de sua posição crítica a Robespierre e Marat, além de contrária à pena de morte de Luís XVI e Maria Antonieta (à qual dedicara sua Declaração dos Direitos da Mulher e da Cidadã) -, foi acusada de aproximação contrarrevolucionária com os girondinos e considerada "perigosa demais". Durante sua atuação, reivindicava a participação política das mulheres por entender que "a mulher nasce livre e permanece igual ao homem em direitos" (ASSMANN, 2018, artigo primeiro, p. 3). Nesse sentido, se a mulher "tem o direito de subir ao cadafalso; [...] [a ela também deve ser reconhecido o direito de] subir à tribuna" (ASSMANN, 2018, artigo dez, p. 3), reafirmando-se a concepção de direito natural iluminista. Para a existência de uma sociedade justa, na visão de Gouges, a mulher não deveria ter sua vida e comportamento subordinados à tirania da vontade do homem, já que era capaz de determinar e julgar por si mesma. A conclusão lógica da autora, e por isso bastante importante para o período, era de que a distinção sexual não poderia subsistir como premissa para o acesso e direito à cidadania.

Já Mary Wollstonecraft (1759-1797) foi uma escritora e filósofa inglesa conhecida por inaugurar os fundamentos da origem da discriminação da mulher. Argumentava que essa origem não é natural, ou melhor, que o que condiciona as mulheres a serem desprovidas de razão é sua falta de formação e educação, direcionando-as à dependência servil do homem. Por meio de sua contribuição, a autora buscou esclarecer o ponto de vista filosófico da mulher naquele contexto social, assim como desnaturalizar e desmentir preconceitos, tornando racional e científica a discussão acerca da "inferioridade natural" da mulher - que, para ela, buscava ser apologética e conservar as relações de dependência e subordinação em relação ao homem. Em sua concepção, contrária às teorias jusnaturalistas tradicionalmente defendidas pelos mais renomados pensadores da época, a subordinação do gênero feminino é agravada pela estrutura patriarcal das famílias e da sociedade, e não porque a mulher seja biológica, física ou intelectualmente inferior e incapaz de ser racional.

Sua discussão tem como chave de pensamento comparar a ideia de que "o homem foi feito para raciocinar, [e] a mulher para sentir" (WOLLSTONECRAFT, 2016, p. 90). Para a autora, a mulher não precisa ter laços matrimoniais ou mesmo ser proprietária para ter a garantia de uma existência civil reconhecida pelo Estado (WOLLSTONECRAFT, 2016, p. 184; 192). Isso a coloca em pé de igualdade com o espírito da época do jacobinismo radical, promovendo um importante giro na abordagem da questão das 
mulheres de um caráter meramente moral e ligado aos costumes para uma questão filosófica, racional e ligada à esfera política. Ainda nesse sentido, sua contribuição ganha originalidade pela qualidade científica de sua investigação, promovendo "uma inflexão na direção da construção de uma teoria política feminista [...] [embora ela], ao tratar dessas questões (com o foco voltado particularmente para a primeira delas), combina a adesão (quase inevitável) às ideias dominantes da época" (MIGUEL; BIROLI, 2014, p. 21).

Afirma Mary Wollstonecraft: "para fazer com que o pacto social seja verdadeiramente equitativo e a fim de difundir esses princípios esclarecedores [propagados pela Revolução], os únicos capazes de melhorar o destino do homem, deve-se permitir às mulheres que lancem os alicerces de sua virtude no conhecimento" (WOLLSTONECRAFT, 2016, p. 224). Ou seja, para ela não bastavam apenas os direitos políticos e econômicos reconhecidos e efetivados para as mulheres, uma vez que elas já manifestavam a necessidade de uma profunda reforma social que também incidisse sobre o comportamento e cultura masculinas, que as degradavam, oprimiam e exploravam com base em um caráter estritamente naturalista e sexista.

Após a queda da monarquia, a nobreza e os membros do alto clero emigrados formaram uma aliança, buscando por apoio nas nações monarcas vizinhas para restaurar o Estado absolutista e impedir que as ideias revolucionárias atingissem outros países por meio da ameaça de intervenção externa da França. Durante esse período ocorreu uma cisão na Assembleia Legislativa - modernamente conhecida pelas designações políticas de "direita", "centro" e "esquerda", em relação às posições da mesma - entre aqueles que queriam dar continuidade ao processo revolucionário e aqueles que entendiam que as principais transformações já haviam sido realizadas pela Constituição de $1791 .^{18}$

Em 1792, com a aprovação da guerra contra a Áustria, uma dupla expectativa passou a ser gerada: para a burguesia, aquela poderia ser uma breve e vitoriosa guerra que fortaleceria sua direção e posição políticas; para a aristocracia, poderia representar uma esperança do retorno de Luís XVI, que, após ser acusado de traição junto a Maria Antonieta, havia sido preso. A pequena burguesia e os camponeses, descontentes com as expropriações e com o fato

\footnotetext{
18 A divisão dos revolucionários de 1789 foi realizada entre: (1) aqueles que queriam dar continuidade ao processo revolucionário e aprofundá-lo (o que significava aumentar os direitos do povo) - chamados de jacobinos, eram formados pela pequena burguesia e apoiado pelos sans-culottes (artesãos e aprendizes, trabalhadores e pequenos proprietários); e (2) aqueles que não queriam aprofundar a revolução, porque temiam a radicalização das massas - chamados de girondinos, eram formados pela alta burguesia aliada aos setores da nobreza e do baixo clero. Os jacobinos, por ocuparem os assentos superiores das sessões, receberam o nome de "montanha" ou "partido da montanha", tendo como seus principais líderes Danton, Marat e Robespierre. Os girondinos receberam esse nome pois ocupavam os bancos inferiores das sessões. $\mathrm{O}$ grupo sem opinião firme era chamado de planície ou pântano - tratava-se das camadas mais baixas, de "cordeliers", camada em que se encontravam os mais pobres, as mulheres, alguns pequenos comerciantes, artesãos e assalariados; e da burguesi financeira de "feuillants" (TROTSKY, 2017, p. 451).
} 
de terem de pagar pelo fim dos direitos feudais, retomaram a violência. A alta burguesia, que se mantinha no poder, proibia a organização sindical e as greves sob pena de morte. Com Paris sitiada pelas tropas prussianas, o povo chama às ruas a defesa da revolução, que leva ao massacre de partidários e defensores do Antigo Regime sob a liderança de Robespierre, Danton e Marat - que distribuíram armas e organizaram a Comuna Insurrecional de Paris.

A Convenção (1792-1795), então, assume o lugar da Assembleia Legislativa devido à ameaça de intervenção externa da Áustria e da Prússia, assim como em função da crise econômica e inflacionária francesa. Inicialmente, foi dirigida pelos girondinos, que queriam consolidar as conquistas burguesas, mas freavam a radicalização da revolução fazendo uma conciliação com o rei e a nobreza. Devido às manifestações populares, os jacobinos - que, diferentemente dos girondinos, queriam aprofundar o processo revolucionário - assumiram o poder revolucionário em 1793 com apoio dos sans-culottes. Dessa maneira, teve início a República Jacobina e a redação da nova Constituição de 1793 (HOBSBAWM, 2016, p. 115117).

A Constituição de 1793 marcou o início da primeira República francesa e um rompimento completo com a Monarquia Constitucional, abolindo-se o voto censitário e instituindo-se o sufrágio universal. A limitação do direito à propriedade privada e a liberdade econômica, a instituição do sistema educacional e de assistência pública (o direito ao trabalho e o direito à existência) e a instituição da liberdade de pensamento, opinião, imprensa e organização foram promovidas. No entanto, devido às imposições de ordem política das lutas entre as classes sociais e suas frações, esse documento nunca foi efetivado concretamente, mas foi capaz de produzir um "legado importante para o século XIX [...] para inspiração das ideologias socialistas [porque] [...] foi revolucionária historicamente, [uma vez que] principiou com a inclusão da igualdade como direito concreto" (PEIXINHO, 2012, p. 5).

Também a partir de 1793 teve início o Período do Terror, marcado pela ascensão de Robespierre e a perseguição, julgamento e guilhotinamento de seus opositores (aristocratas, clérigos, girondinos, inimigos reais e presumidos da Revolução). Os girondinos sobreviventes, assim como a burguesia moderada, já exaustos pela radicalização e excessos revolucionários dos jacobinos, articularam um golpe - conhecido como Termidor -, que, por meio da Convenção Termidoriana (1794-1795), marcou a decadência do período revolucionário com o fim da Comuna Insurrecional de Paris e a queda de Robespierre e seus partidários jacobinos, os sans-culottes e a pequena burguesia (HOBSBAWM, 2016, p. 117). 
Em 1795, a Convenção elaborou uma nova Constituição que retrocede em relação à anterior em termos de direitos fundamentais reconhecidos como conquistas da Revolução, como

\begin{abstract}
A expressão que dispunha que os homens nascem livres e iguais em direitos por se temer que fosse exigida a igualdade econômica como ocorrera na Declaração de 1793. Desaparecem os direitos fundamentais que consagravam a felicidade comum como fim da sociedade, o direito ao trabalho, à assistência social, à educação e o direito à insurreição. O mais visível dos retrocessos foi a eliminação do sufrágio universal e o restabelecimento do voto censitário. (PEIXINHO, 2012, p. 6)
\end{abstract}

Além de tudo isso, teve início a proibição da Sociedade das Cidadãs Republicanas Revolucionárias e dos clubes políticos femininos e mistos. Como aborda Morin (2016, p. 193), mesmo dentro dos limites do ideário burguês da época, a Sociedade foi apontada como "uma possível conexão política [contrarrevolucionária] entre os girondinos e as Republicanas Revolucionárias, que, ao contrário, eram próximas dos Enragées”. Esse ataque às militantes e ativistas republicanas partiu tanto do setor dos montanheses como de mulheres aristocratas e da alta burguesia, que, além de não reconhecerem os direitos políticos das mulheres em geral, eram contrárias à sua participação política, buscando retomar as reivindicações e concepções conservadoras de "maternidade cívica" em conjunto com os homens (MORIN, 2016, p. 186).

No final do ano de 1795, a Convenção cedeu lugar ao Diretório (1795-1799), um período conservador marcado pelo retorno da alta burguesia ao poder e pela insatisfação das massas. Em 1796, também ocorreu a tentativa de organizar a Conspiração dos Iguais (conhecida como o primeiro movimento popular socialista), liderada por Graco Babeuf, por meio da crítica à propriedade privada que inspirará a luta operária do século XIX (HOBSBAWM, 2016, p. 127). Diante disso, a alta burguesia "eliminou a declaração de direitos e dispôs, exclusivamente, sobre princípios orgânicos que legitimou a ditadura, mas conservou, oficialmente, a forma republicana" (PEIXINHO, 2012, p. 7), sendo necessário recorrer a uma figura de caráter autoritário e militar. Sobressaiu-se, portanto, Napoleão Bonaparte, que suprimiu o Diretório e instaurou o Consulado (1799-1804) por meio de um golpe de Estado que ficou conhecido como 18 de Brumário - quando Napoleão estabeleceu-se como primeiro cônsul e deu início ao período napoleônico, marcando definitivamente a decadência do processo revolucionário da burguesia francesa.

Durante o Império Napoleônico, as guerras de expansão e conquista (18031815) foram fundamentais para difundir os ideais da revolução burguesa e 
combater o absolutismo monárquico. Em 1804, foi criado o Código Civil Napoleônico, que cumpria a função de salvaguardar a propriedade privada burguesa, além de proibir sindicatos e greves e até mesmo, particularmente, o direito ao divórcio (HOBSBAWM, 2016, p. 129131). Por conseguinte, a restauração do poder monárquico com Luís XIII marca o fim do Império Napoleônico, expresso na nova Constituição de 1814.

Sobre esse período, é importante ressaltar que, de "1793 a 1795, os homens de todas as classes sociais e níveis de renda tiveram plenos direitos políticos. [No entanto,] as mulheres que contribuíram para este avanço democrático não foram incluídas” (MORIN, 2013, p. 138), ou seja, as mesmas que haviam participado diretamente da revolução tinham agora sua luta e engajamento políticos ignorados com a ideia de "maternidade cívica"19. Por essa concepção naturalista e fundamentada na desigualdade entre os sexos, elas deveriam voltar-se para as atividades domésticas e para os deveres maternos, como forma de garantir que as "mulheres virtuosas" - esposas e mães - construíssem as bases da República da Virtude, sob um forte apelo à moral republicana. Apoiava-se a noção de que, ao educarem seus filhos, estariam preparando a futura geração de patriotas. Essas mulheres eram os modelos que estavam em contraposição às "mulheres perigosas", que participavam da atividade pública, do ativismo e da militância políticas.

Influenciados por teóricos como Rousseau, "muitos homens [...] eram reticentes ou hostis à atuação das associações femininas quando suas atividades ultrapassavam a filantropia para entrar no terreno político - e masculino" (MORIN, 2013, p. 130). Assim, muitos dos grandes pensadores e revolucionários da época ainda eram temorosos quanto ao alcance dos clubes femininos e da participação política das mulheres, pois esta acabava por questionar as relações sociais estabelecidas e o comportamento masculino. Os homens se encontram em situação confortável, já que "não estão dispostos a colocar as mulheres em situações próprias a fim de capacitá-las a obter entendimento suficiente" (WOLLSTONECRAFT, 2016, p. 227). Outro exemplo de rejeição às mulheres cidadãs e revolucionárias foi a "expressão da moral

\footnotetext{
${ }^{19}$ Para Wollstonecraft, a sociedade educava as mulheres para serem agradáveis às vistas de seus maridos, pais e governantes. Elas ocupavam sua educação com futilidades ou atividades do âmbito doméstico, e por vezes não sabiam se o que faziam era por hábito (costume) ou porque queriam e decidiram fazer devido às debilidades de seu processo formativo. Destinar as mulheres à obrigatoriedade da vida e trabalhos domésticos (casar, cuidar do lar e dos filhos) para reproduzir o ideal de família, além de não contribuir para emancipar as mulheres, não contribuía para desenvolver suas faculdades intelectuais, o que também implicaria não ser uma boa mãe - e consequentemente uma boa esposa -, pois a mulher não tinha o direito de escolher por si mesma. Sobre essa questão, ela comenta: “[...] nós não veremos mulheres afetuosas até que se estabeleça mais igualdade na sociedade, até que as posições se misturem e as mulheres se libertem, tampouco veremos aquela felicidade doméstica dignificada, cuja grandiosidade não pode ser apreciada pelas mentes ignorantes ou viciadas; nem a importante tarefa da educação será adequadamente iniciada, até que a figura de uma mulher não seja mais apreciada do que sua mente. Pois seria tão sensato separar o joio ou figos do cardo quanto imaginar que uma mulher tola e ignorante seria uma boa mãe" (WOLLSTONECRAFT, 2016, p. 245).
} 
conservadora da exaltação das virtudes domésticas e dos papéis de gênero bem definidos, [...] compartilhada com os padrões burgueses" (MORIN, 2013, p. 203). A forma de participação das mulheres na vida pública se dava por meio do tricô e da costura nas tribunas, enquanto os deputados homens discursavam.

\section{CONSIDERAÇÕES FINAIS}

Após abordarmos o período da Revolução Francesa, de 1789 a 1799, a partir do desenvolvimento das relações de produção capitalistas - visto que a base material da sociedade é constituída pelas relações de produção capitalistas e pelas forças produtivas - e da gênese socioeconômica das reivindicações dos direitos da mulher na modernidade, podemos compreender como as mulheres (camponesas, proletárias e pequeno-burguesas) desse período desempenharam um papel central ao questionar as bases da nova ordem social que efervescia.

Com a fundação dos clubes políticos femininos e mistos foi possível delinear e também diferenciar as posições políticas das mulheres participantes e ativas na vida pública, pois suas posições, ora mais abertas, ora mais conservadoras, questionavam a centralidade das teorias jusnaturalistas e teológicas que inferiorizavam as mulheres na sociedade.

Nesse sentido, é possível compreender as particularidades dos textos apresentados por Olympe de Gouges, em 1791, e por Mary Wollstonecraft, em 1792, acerca da emancipação política da mulher, pois ambas as contribuições foram fundamentais para o período, marcando os primeiros apontamentos de insuficiência do programa político-econômico da burguesia em efetivar os direitos que havia assumido como universais, dado que excluíam as mulheres dos direitos políticos.

A reflexão-chave do pensamento de Gouges pode ser resumida na ideia de que as relações sociais fundamentadas pela distinção sexual não poderiam existir como princípios para o acesso e direito à cidadania. Tal ideia foi radicalizada especialmente por Wollstonecraft, que, não apenas por seu envolvimento e atividade no referido período, assumia o aspecto ideológico da burguesia revolucionária da época; ao tomar a pretensão universal das reivindicações políticas e econômicas, buscava manifestá-las filosoficamente como uma questão que se relacionava e abarcava as mulheres das mais distintas classes sociais. 
Apesar desses limites e equívocos, a posição de Wollstonecraft também carregava elementos que denunciavam as condições das mulheres proletárias, camponesas e pequenoburguesas, além de outras tendências e grupos sociais, mesclando tais elementos filosófica e politicamente em seus escritos e em sua prática política no referido período.

Nesse sentido, por fim, a expressão geral mais característica foi realizada, ainda que de forma documental, pela Constituição de 1793 e pela Declaração de Direitos Jacobina, possibilitando um acúmulo de experiências e debates políticos para o legado histórico dos movimentos socialistas no século XIX. 


\section{REFERÊNCIAS BIBLIOGRÁFICAS}

ABBAGNANO, Nicola. Dicionário de filosofia. 5 ed. Trad. Alfredo Bossi e Ivone Castilho Benedetti. São Paulo: Martins Fontes, 2007.

ABRÃO, Bernadete Siqueira (org.). História da filosofia (Os Pensadores). São Paulo: Nova Cultural, 1999.

ASSMANN, Selvino José. Declaração dos Direitos da Mulher e da Cidadã - por Marie Gouze, "Olympe de Gouges" (1791). In: Revista Internacional Interdisciplinar INTERthesis, Florianópolis, v. 15, n. 1, fev. 2018. ISSN 1807-1384. Disponível em: $<$ https://periodicos.ufsc.br/index.php/interthesis/article/view/54986>. Acesso em: $16 \mathrm{de}$ março de 2019.

D’ATRI, Andrea. Pão e rosas: identidade de gênero e antagonismo de classe no capitalismo. 2 ed. Trad. Barbara Molnar, Flavia Toledo e Lara Zaramella. São Paulo: Edições Iskra, 2017.

HOBSBAWM, Eric. A era das revoluções (1789-1848). 36 ed. Rio de Janeiro: Paz e Terra, 2016.

HUNT, Emery Kay. História do pensamento econômico. 7 ed. Trad. José Ricardo Brandão Azevedo. Rio de Janeiro: Elsevier, 1981.

JAMES, Cyril Lionel Robert. Os jacobinos negros: Toussaint L'Ouverture e a revolução de São Domingos. Trad. Afonso Teixeira Filho. São Paulo: Boitempo, 2010.

KANT, Immanuel. Resposta à pergunta: que é "esclarecimento" (Aufklärung)? In: . Textos seletos. 9 ed. Petrópolis, Rio de Janeiro: Vozes, 2013.

MANDEL, Ernest. O lugar do marxismo na história. 2 ed. São Paulo: Xamã, 2001.

MARX, Karl. O capital: crítica da economia política, livro I. Trad. Rubens Enderle. São Paulo: Boitempo, 2013.

MIGUEL, L.; BIROLI, F. Feminismo e política: uma introdução. São Paulo: Boitempo, 2014.

MORIN, Tania Machado. Virtuosas e perigosas: as mulheres na Revolução Francesa. São Paulo: Alameda, 2014.

PEIXINHO, Manoel Messias. Os direitos fundamentais nas Constituições francesas. In: Anais do XXI Congresso Nacional do CONPEDI. Florianópolis: CONPEDI Conselho Nacional de Pesquisa e Pós-Graduação em Direito, 2012. Disponível em: 
〈http://www.publicadireito.com.br/artigos/?cod=b1bc40d056bad6ec $>$. Acesso em: 15 de março de 2019.

RUBIN, Isaac Ilich. História do pensamento econômico. Trad. Enderle. Rio de Janeiro: Editora UFRJ, 2014.

TROTSKY, Leon. A teoria da revolução permanente. São Paulo: Editora Instituto José Luís e Rosa Sundermann, 2010.

. O Termidor francês. In: Stalin: uma análise do homem e de sua influência. São Paulo: Editora Marxista; Porto Alegre: Editora Movimento, 2017.

WOLLSTONECRAFT, Mary. Reivindicação dos direitos da mulher. Trad. Ivania Pocinho Motta. São Paulo: Boitempo, 2016. 